\title{
Peran Kultur Sekolah dalam Pengembangan Soft Skill Siswa di SMA Piri 1 Yogyakarta
}

\author{
PIPIT ELVA NOVITA DAN AMAN \\ Program Studi Pendidikan Ilmu Sosial PPs UNY \\ Fakultas Ilmu Sosial Universitas Negeri Yogyakarta \\ pipitelva22@gmail.com
}

\begin{abstract}
Abstrak
Penelitian ini bertujuan mendeskripsikan: (1) realita kultur sekolah, (2) bentuk kultur sekolah, (3) penerapan prinsip demokrasi oleh kepala sekolah, (4) realita soft skill siswa, dan (5) Faktor pendukung pengembangan soft skill siswa; di SMA PIRI 1 Yogyakarta. Metode yang digunakan adalah kualitatif deskriptif dengan teknik pengumpulan data observasi, wawancara dan dokumentasi. Analisis data dengan mengklasifikasikan, menginterpretasikan dan memverifikasi data dari lapangan. Hasil penelitian: (1) realita kultur sekolah nampak dari artifak-artifak yang ada yaitu slogan, peraturan, cerita, upacara, simbol, logo, dan gambar,2) bentuk kultur sekolah nampak dari pelaksanaan nilai-nilai islami, kerjasama saling menghargai dan saling mendukung, serta penegakan disiplin dan tanggungjawab,(3) kepala sekolah menerapkan prinsip demokrasi dalam pembagian tugas dan tanggungjawab,(4) Realita soft skill siswa dilihat pada kemampuan interpersonal dalam berhubungan dan berkerjasama, nampak pada kemampuan mengendalikan emosi, menerima nasehat, dan selalu berpikir positif,(5) faktor pendukung pengembangan soft skill siswa bersumber dari peraturan sekolah dan partisipasi warga sekolah.
\end{abstract}

Kata kunci: Kultur Sekolah, Pengembangan, dan Soft Skill.

\begin{abstract}
This research aims to describe: (1) the reality of school culture, (2) forms of school culture, (3) application of the principles of democracy by the principal, (4) the reality of students' soft skills, and (5) Factors supporting the development of soft skills of students at SMA PIRI 1 Yogyakarta. The method used in this research is descriptive qualitative. The data collection techniques include observation, interviews and documentation. The analysis of the data was performed by classifying, interpreting and verifying the data from the field. The findings of the research include: (1) the reality of school culture appears from artifacts in which there is a slogan, rules, stories, ceremonies, symbols, logos, and images, 2) the form of the school culture appears from the implementation of Islamic values, cooperation, mutual respect and mutual support, as well as the enforcement of discipline and responsibility, , (3) the principal implement democratic principles in the division of tasks and responsibilities, (4) The students' soft skills can be viewed from the interpersonal skills in dealing and cooperating and from the ability to control emotions, to receive advice, and to think positively, (5) the supporting factors of the students soft skills development come from the school rules and the school community participation.
\end{abstract}

Keywords: school culture, development, and Soft Skills. 


\section{PENDAHULUAN}

Kualitas pendidikan suatu negara sangat penting karena sangat menetukan pembangunan bangsa tersebut, karena pendidikan merupakan sarana yang sangat sentral dan strategis untuk mendukung keberhasilan pembangunan. Ada beberapa kelemahan yang mengakibatkan rendahnya kualitas pendidikan di Indonesia, antara lain (1) pemerintah terlalu berkeinginan untuk menguasai sektor pendidikan, (2) perhatian utama untuk meningkatkan mutu pendidikan selalu difokuskan pada pembelajaran, (3) para guru selalu dituntut untuk memberikan pelayanan yang lebih baik kepada siswa sementara nasib mereka sendiri tidak diperhatikan dengan sungguh-sungguh, (4) selama ini pendidikan di Indonesia tidak memiliki standar mutu (benchmark) yang diingikan, (5) birokrasi pendidikan di Indonesia dijalankan oleh orang-orang yang tidak mengerti hakikat pendidikan yang sesungguhnya (Nurkolis, 2006: 16).

Penelitian-penelitian yang telah dilakukan menunjukan bahwa pendekatanpendekatan konvensional dalam meningkatkan mutu dengan menyediakan dana meningkatkan kualitas serta kuantitas variabel input, seperti pelatihan guru, penyediaan buku teks, penyediaan fasilitas pendidikan yang lain, tidaklah menghasilkan sebagaimana yang diinginkan. Oleh karena itu, agar mutu meningkat, selain dilakukan secara konvensional perlu diiringi pula dengan pendekatan inkonvensional yakni meningkatkan mutu pengembangan kultur sekolah.

Kultur sekolah memiliki dua lapisan. Lapisan pertama sebagian dapat diamati dan sebagian tidak teramati. Lapisan yang bisa diamati seperti: arsitektur, tata ruang, eksterior dan interior, kebiasaan dan rutinitas, peraturan-peraturan, cerita-cerita, upacaraupacara, ritus-ritus, simbol, logo, slogan, bendera, gambar-gambar, tanda-tanda, sopan santun, dan cara berpakaian. Lapisan pertama kultur berupa norma-norma kelompok atau yang telah dimiliki kelompok. Normanorma perilaku ini umumnya sukar diubah. Lapisan pertama ini biasa disebut dengan artifak. Lapisan kedua berupa nilai-nilai ber- sama yang dianut kelompok berhubungan dengan apa yang penting, baik, dan benar. Lapisan kedua semuanya tidak dapat diamati karena terletak di dalam kehidupan bersama. Jika lapisan pertama yang berintikan norma prilaku bersama sukar diubah, lapisan kedua yang berintikan nilai-nilai dan keyakinan sangat sukar diubah serta memerlukan waktu untuk berubah.

Kultur sekolah adalah kualitas kehidupan yang mewujud dalam aturan-aturan atau norma, tata kerja, kebiasaan kerja, gaya kepemimpinan seorang pemimpin maupun anggota yang ada di sekolah. Kualitas kultur di sekolah akan tumbuh dan berkembang berdasarkan nilai-nilai, spirit, atau aturan yang telah disepakati di sekolah.

Konsep kultur sekolah yang baik harus seimbang antara kultur yang bersifat batiniah dan lahiriah, sehingga sekolah akan maju. Di sisi lain sekolah akan berkualitas apabila kultur sekolah ditumbuh kembangkan pada seluruh civitas sekolah yang terdiri dari kepala sekolah, para guru, para pekerja kependidikan, dan siswa. Kultur sekolah merupakan nilai-nilai, keyakinan-keyakinan, slogan-slogan atau moto, kebiasan-kebiasaan dan upacaraupacara yang telah dikembangkan dalam waktu yang lama dan dipegang teguh oleh seluruh warga sekolah dan diturunkan kepada generasi selanjutnya yang dipergunakan sebagai pegangan dalam memajukan pendidikan di sekolah (Zamroni, 2007:109-110). Apabila sekolah mempunyai keinginan untuk bermutu harus ada kesepakatan antara pihak sekolah dan para pendukungnya. Kepala sekolah dan guru hanya sebagai pemandu dalam proses menuju sekolah yang bermutu karena proses tersebut tidak dengan waktu yang singkat tetapi perlu proses yang panjang (Hanum, 2011:111-112).Mencermati pendapat di atas dapat dijelaskan secara ideal, setiap sekolah tentu harus memiliki spirit, nilai-nilai, keyakinan-keyakinan, slogan-slogan atau moto, kebiasaan-kebiasaan dan upaara-upacara yang baik.

Kultur sekolah bersumber dari spirit dan nilai-nilai yang dianut oleh sekolah. Zamroni (2002:32-35) menjelaskan nilai-nilai tersebut menjadi sumber kualitas kehidupan se- 
kolah dalam rangka menumbuhkembangkan kecakapan hidup siswa.

Meningkatkan kultur sekolah yang baik perlu kerjasama yang baik dengan pihak sekolah dengan orang yang peduli terhadap pendidikan dan butuh waktu yang cukup lama. Berdasarkan Pendapat tersebut, dapat diketahui bahwa kultur sekolah merupakan hal yang sangat penting untuk diperhatikan dan dikembangkan. Kultur sekolah akan secara langsung dan tidak langsung dapat mempengaruhui soft skill serta minat siswa dalam mengikuti proses pembelajaran di sekolah. Kondisi kultur sekolah yang baik, aman, dan nyaman bagi siswa akan dapat mendatangkan ketentuan dan soft skill bagi siswa dalam belajar.

Lapisan kultur sekolah dibagi menjadi tiga, yaitu artifak dipermukaan, nilai-nilai dan keyakinan di tengah, dan asumsi lapisan dasar. Artifak adalah lapisan kultur sekolah yang paling mudah diamati seperti aneka ritual sehari-hari di sekolah, berbagai upacara, benda-benda simbolik di sekolah, dan aneka ragam kebiasaan yang berlangsung di sekolah. Keberadaan kultur ini dengan cepat dapat dirasakan ketika orang mengadakan kontak dengan suatu sekolah. Aspek kultur ini kemudian dimanifestasikan dalam aspek kultur yang nyata dan diamati, yakni artifak fisik maupun prilaku, dengan demikian keadaan fisik dan prilaku warga sekolah didasari oleh asumsi, nilai-nilai dan keyakinan (Zamroni, 2002:25).

Kepala sekolah sebagai sentral pengembangan kultur sekolah harus dapat menjadi contoh dalam berinteraksi di sekolah. Kepala sekolah adalah figur yang memiliki komitmen terhadap tugas sekolah, jujur dalam kata dan perbuatan dan selalu bermusyawarah dalam membuat kebijakan sekolah, rumah dan menghargai pendapat orang lain. Selain itu, kepala sekolah merupakan model bagi warga sekolah (Zamroni, 2013:44).

Asmani (2009:17) menjelaskan dalam kultur sekolah tersebut bahwa seorang pendidik (guru) sebaiknya tidak bersifat otoriter. Guru harus sering memberikan kesempatan kepada siswa agar dapat mencapai pendapatnya, sehingga siswa menjadi tidak mem- punyai rasa takut apabila berhadapan dengan guru. Seorang guru tidak boleh merasa dirinya paling pintar, walaupun yang dihadapi adalah seorang siswa.

Keadaan pemikiran di atas secara otomatis peran guru dalam menciptakan kultur sekolah memberi pengaruh yang besar terhadap proses pembelajaran yang dilakukan di sekolah. Guru merupakan sosok yang harus bisa menjadi pentransfer nilai-nilai dan ilmu pengetahuan kepada siswa, sekaligus menjadi teladan dan sosok yang dapat dijadikan figur untuk diteladani oleh siswa. Ini dilakukan guru untuk menciptakan kultur sekolah yang mencerminkan nilai-nilai kultur sekolah yang termasuk diantaranya yaitu nilai keyakinan akan nilai-nilai serta kebiasaankebiasaan, yang dilaukan untuk dapat menjadi pegangan bagi siswa dalam menghadapi berbagai permasalahan yang dihadapi (Zamroni, 2013:7).

Selain pembentukan kultur sekolah yang dilakukan di dalam kelas, semua warga sekolah juga harus membentuk kultur sekolah yang kondusif di luar kelas. Kultur sekolah di luar kelas ini seperti adanya pembentukan kebiasaan-kebiasaan positif yang harus diterapkan oleh semua warga sekolah, seperti membiasakan senyum ketika bertemu guru dan teman sebaya, membiasakan untuk menjaga kebersihan lingkungan sekolah, tidak berkata-kata kasar, dan tidak berbuat keributan. Kesemuanya itu diharapkan akan dapat membentuk mental positif siswa dalam kehidupan sehari-hari, baik ketika berada di lingkungan sekolah bahkan ketika berada di tempat tinggal siswa (Zamroni, 2002: 35).

Penerapan kultur sekolah yang positif di luar kelas ini sangat penting, terutama untuk membiasakan siswa dalam berinteraksi dengan orang lain.Mengembangkan kultur sekolah yang baik terutama kepada siswa, guru harus dapat memberikan contoh kepada siswanya (Nurkolis, 2006:64).

Membangun kultur sekolah, seorang kepala sekolah atau pemimpin harus memberi perhatian terhadap aspek informal, aspek simbolik, dan aspek yang tak tampak dari kehidupan sekolah yang telah membentuk keyakinan dan tindakan tiap warga seko- 
lah. Kepala sekolah mempunyai tugas dalam menciptakan atau membentuk dan mendukung kultur yang diperlukan untuk menguatkan sikap yang efektif dalam segala hal yang dikerjakan di sekolah. Apabila sikap ini timbul dan didukung oleh kultur, semua aspek lain akan selalu berjalan beriringan (Zamroni, 2007: 55).

Melihat peran kultur sekolah yang begitu signifikan dalam mempengaruhi proses pembelajaran yang dilakukan di sekolah, dibutuhkan adanya kerja sama antara semua warga sekolah, mulai dari kepala sekolah, guru, semua staf. Ini menunjukkan bahwa upaya pembentukan kultur sekolah merupakan tanggung jawab semua warga sekolah, yang dilakukan dengan kesungguhan dan loyalitas tinggi. Kultur sekolah yang baik harus dapat mencerminkan nilai-nilai yang bersahabat dan mendatangkan kesan yang positif bagi siswa, baik di luar kelas maupun di dalam kelas. Hal penting yang perlu diperhatikan dalam menerapkan kultur sekolah yang baik di dalam kelas adalah menempatkan kelas sebagai ruang belajar yang mendidik, memberikan kepuasan tersendiri, dan menghasilkan praktik pendidikan yang bermutu (Yamin, 2008:208).

Menurut Zamroni (2013:7-8) kultur diyakini mempengaruhi perilaku seluruh komponen sekolah, yaitu: guru, kepala sekolah, staf administrasi, siswa, dan juga orang tua siswa. Kultur yang kondusif bagi peningkatan mutu akan mendorong perilaku warga ke arah peningkatan mutu sekolah, sebaliknya kultur yang tidak kondusif akan menghambat upaya menuju peningkatan mutu sekolah. Kultur yang kondusif seperti kultur yang mendorong siapapun warga sekolah malu kalau tidak disiplin, siswa malu kalau tidak mengerjakan pekerjaan rumah, mendorong kepala sekolah untuk berbuat adil dan tegas.

Kultur sekolah yang baik dapat berpengaruh terhadap pengembangan soft skill siswa. Soft skills adalah ketrampilan seseorang dalam berhubungan dengan orang lain (termasuk dengan dirinya sendiri). Artribut soft skills, dengan demikian meliputi nilai yang dianut, motivasi, perilaku, kebiasaan, karakter dan sikap (Neff \& Citrin, 2001:17).Aspek dari soft skill meliputi kemampuan interpersonal dan kemampuan personal. Kemampuan interpersonal berupa kemampuan berkomunikasi dan bekerjasama. Sedangkan kemampuan personal meliputi kesadaran diri dan kecakapan berpikir.

\section{METODE}

Subjek penelitian ini adalah kepala sekolah wakil kepala sekolah, guru, staf administrasi sekolah dan siswa di SMA PIRI 1 Yogyakarta. Objek penelitian adalah peran kultur sekolah, dan pengembangan Soft skill siswa di SMA PIRI 1 Yogyakarta.

Metode yang digunakan adalah kualitatif deskriptif dengan teknik pengumpulan data observasi, wawancara dan dokumentasi.Analisis data dilakukan dengan mengklasifikasikan, menginterpretasikan dan memverifikasi data yang diperoleh dari lapangan. Teknik keabsahan data menggunakan teknik trianggulasi sumber dan trianggulasi metode.

\section{HASIL DAN PEMBAHASAN}

Hasil penelitian peran kultur sekolah dalam pengembangkan Soft Skillsiswa SMA PIRI 1 Yogyakarta dapat dilihat dari1) Realita kultur sekolah, 2) Bentukkultur sekolah, 3) Peran kultur sekolah dalam pengembangan soft skill siswa, 4) Realitas soft skill siswa, dan 5) Pendukung soft skill siswa.

\section{Hasil Penelitian Realita Kultur Sekolah di SMA PIRI 1 Yog- yakarta}

Realita kultur sekolah di SMA PIRI 1 Yogyakarta ini dapat dilihat pada aspek artifak. Kultur sekolah pada aspek artifak menggambarkan kondisi sekolah, yaitu aneka ritual sehari-hari di sekolah, berbagai upacara, benda-benda simbolik di sekolah, dan aneka ragam kebiasaan yang berlangsung di sekolah. Pada aspek artifak yang ada di SMA PIRI 1 Yogyakarta dapat dilihat pada gambaran lingkungan fisik dan lingkungan belajarnya.

Iklim belajar yang kondusif merupakan tulang punggung dan faktor pendorong yang dapat memberikan daya tarik tersendiri bagi proses pembelajaran, sebaliknya iklim yang kurang menyenangkan akan menimbulkan 
kejenuhan dan rasa bosan. Iklim belajar yang kondusif harus ditunjang oleh berbagai fasilitas belajar yang menyenangkan, seperti sarana, laboratorium, pengaturan lingkungan, penampilan dan sikap guru, hubungan yang harmonis antara guru dengan peserta didik, bahan pembelajaran yang tepat dan sesuai dengan kemampuan dan perkembangan peserta didik (Zamroni, 2007:165).

Lingkungan Fisik. Gedung sekolah SMA PIRI 1 Yogyakarta terdiri dari tiga lantai dengan tata ruang yang selaras, pada lantai satu di SMA PIRI 1 Yogyakarta terdapat ruang tata usaha, dimana ruang tata usaha merupakan ruang yang melengkapi administrasi dan kebutuhan sekolah, ruang tata usaha juga terdapat lemari yang menyimpan piala-piala prestasi siswa dan di depan ruang tata usaha terdapat papan tidak hadir siswa dan papan informasi sekolah. Letak ruang tata usaha juga berdampingan dengan ruang kepala sekolah SMA PIRI 1 Yogyakarta. Posisi yang bersebelahan ini juga tempat yang strategis untuk memberi kemudahan warga sekolah apabila ingin menemui kepala sekolah. Di ruang kepala sekolah terdapat monitor pengamatan untuk mengetahui keadaan di sekeliling sekolah, dan keadaan ruang guru. Cctv yang terpasang di depan ruang tunggu dan ruang guru bertujuan sebagai alat pembantu pengamatan keadaan sekolah.

Slogan-slogan yang dimiliki di SMA PIRI 1 Yogyakarta tidak hanya ditempel di dindingdinding luar ruangan saja namun di dalam ruang guru juga terpasang slogan-slogan pesan moral. Bahwa hal ini mengambarkan slogan-slogan yang dipasang di setiap dinding sekolah tidak hanya untuk siswa saja namun slogan-slogan tersebut untuk seluruh warga sekolah di SMA PIRI 1 Yogyakarta.

Lingkungan Belajar. Proses belajar mengajar yang bermutu adalah proses yang dapat meningkatkan pengetahuan dan kemampuan siswa secara optimal. Proses belajar mengajar tentunya tidak dapat terlepas dari fasilitas pendukungnya seperti media pembelajaran, ruang belajar yang nyaman, perpustakaan, laboratorium dan sebagainya. Ruang kelas yang nyaman akan memberi kenyamanan dan kemudahan siswa dan guru di dalam proses pembelajaran.

\section{Bentuk Kultur Sekolah di SMA PIRI 1 Yo- gyakarta}

Bentuk kultur sekolah yang ada di SMA PIRI 1 Yogyakarta dapat dilihat sebagai berikut.

Nilai Islami. Kegiatan-kegiatan keislaman yang dilakuakn warga SMA PIRI 1 Yogyakarta baik yang dilakukan secara rutin maupun kegiatan pendukung tersebut menunjukan bahwa sekolah ini memiliki upaya untuk menanamkan pemahaman keislaman kepada seluruh warga sekolah. Hal tersebut sesuai dengan visi dan misi yang dimiliki sekolah SMA PIRI 1 Yogyakarta

Menumbuhkembangkan wawasan keislaman sehingga muncul akhlak karimah pada seluruh warga sekolah.pelaksanaan nilainilai Islami yaitu kegiatan darus Al-quran, doa bersama disetiap pagi, shalat dzuhur berjama'ah dan kajian Islam untuk siswa putri pada waktu shalat jumat berlangsung.

Disiplin. Prilaku disiplin sangat diperhatikan di SMA PIRI 1 Yogyakarta. Disiplin sangat diperlukan untuk menciptakan efisiensi pendidikan agar tidak terjadi kesia-siaan dalam proses pembelajaran. Penegakan disiplin merupakan upaya menciptakan sikap dan prilaku warga sekolah tidak menyimpang dari norma-norma yang berlaku. Disiplin diartikan sebagai kepatuhan terhadap peraturan atau patuh terhadap pengawasan serta pengendalian dari pihak sekolah. Akan tetapi disiplin juga dapat digunakan sebagai sarana latihan yang bertujuan untuk mengembangkan diri agar dapat berprilaku tertib sesuai dengan norma yang berlaku.

Kerjasama. Kerjasama yang terjalin di SMA PIRI 1 Yogyakarta terbilang cukup baik, dengan adanya team work di dalam sekolah menunjukan bahwa seluruh elemen yang ada di dalam sekolah akan terciptanya sikap saling menghargai, saling pengertian dan saling mendukung antar sesama warga sekolah

Pengertian dan sikap saling mendukung tersebut tentu dalam arti yang positif dan dapat meningkatkan kualitas sekolah. Sikap mementingkan keinginan pribadi yang dapat menghambat tujuan sekolah tentu dapat di- 
minimalisir dengan adanya kerjasama yang solid tersebut karena sudah adanya kesadaran akan tanggung jawab yang dimiliki oleh semua warga sekolah SMA PIRI 1 Yogyakarta.

Apresiasi Terhadap Prestasi. Adanya kebebasan dari pihak sekolah kepada guru dan siswa untuk mengembangkan minat dan bakat maka akan tercipta kultur untuk berprestasi di dalam sekolah. Kebebasan tersebut juga menciptakan semangat berkompetisi yang positif di antara warga sekolah. Hal ini tentu sesuai dengan misi yang dimiliki oleh pihak sekolah yakni menumbuhkembangkan semangat keunggulan secara intensif kepada seluruh warga sekolah. Makna dari misi tersebut menunjukkan bahwa sekolah selalu memberikan dukungan dan bantuan serta mau untuk berkejasama. Warga sekolah untuk berkompetisi sehingga dapat meraih prestasi yang membanggakan serta mengharumkan nama sekolah SMA PIRI 1 Yogyakarta.

Prestasi yang didapat sekolah juga dapat digunakan sebagai indikator keberhasilan sekolah. Semakin banyak prestasi yang diraih oleh warga sekolah maka dapat mengembangkan semangat untuk berprestasi. Prestasi yang didapat sekolah juga dapat dijadikan metode evaluasi bagi sekolah di SMA PIRI 1 Yogyakarta. Jika prestasi yang dihasilkan mengalami penurunan, hal tersebut akan melakukan perbaikan dari pihak sekolah kepada warganya guna mendapatkan semangat kembali atau motivasi dan meraih prestasi.

\section{Peran Kultur Sekolah Dalam Pengemban- gan Soft Skill Siswa di SMA PIRI 1 Yogya- karta}

Peran kultur sekolah dalam pengembangan soft skill siswa di SMA PIRI 1 Yogyakarta dapat dilihat dari visi dan misinya. Kualitas sekolah berawal dari adanya visi sekolah, yang kemudian dijabarkan dalam misi sekolah (Zamroni, 2013, p. 13). Visi dan misi tersebut menjadi pedoman bagi warga sekolah untuk bertindak dan berprilaku di dalam lingkungan sekolah. Visi SMA PIRI 1 Yogyakarta adalah "Berdaya saing dalam prestasi dan teknologi, berwawasan lingkungan serta berahlak mulia". Visi SMA PIRI 1 Yogyakarta dibuat berdasarkan tujuan pendidikan nasional. Tujuan pendidikan nasional adalah menjadikan manusia yang beriman dan bertaqwa terhadap Tuhan Yang Maha Esa.

Kepala sekolah sebagai pemimpin sangat mempengaruhi maju dan mundurnya kultur sekolah yang akan mengembangkan kualitas soft skill siswa di SMA PIRI 1 Yogyakarta. Kepala sekolah di SMA PIRI 1 Yogyakarta menerapkan demokratisasi dan eksistensi pembagian tugas serta tanggungjawab terhadap warga sekolah. Kepala sekolah berupaya menerapkan konsep pendidikan dan peningkatan kualitas pendidikan (guru, siswa, kurikulum, bahan ajar dan proses pembelajaran). Kepala sekolah selalu melakukan koordinasi dan konslidasi dengan komite sekolah.

Kepala sekolah SMA PIRI 1 Yogyakarta memiliki perogram tentang pelatihan kepada guru-guru yang masih kurang di dalam penggunaan komputer (teknologi), bertujuan memberi pembelajaran yang berfariasi untuk siswa agar siswa tidak merasa bosan di dalam pembelajaran yang diberikan. Kepala sekolah memprogram suasana pendidikan yang bermakna, menyenangkan, kreatif, dinamis dan dialogis sehingga terwujud iklim akademik. Kepala sekolah, guru, dan tata usaha di SMA PIRI 1 Yogyakarta memiliki kepekaan sosial yang sangat baik terhadap siswa, misalnya ada siswa yang kurang mampu, guru berinisiatif membantu siswa yang sedang kesulitan keuangan, tanpa harus saling tujuk untuk membantu siswa yang sedang kesulitan keuangan.

\section{Realita Soft Skill Siswa di SMA PIRI 1 Yog- yakarta}

Realita soft skill siswa di SMA PIRI 1 Yogyakarta dapat dilihat dari kemampuan interpersonal dan kemampuan personal, yaitu.

Kemampuan Interpersonal. Kemampuan berinteraksi siswa di SMA PIRI 1 Yogyakarta cukup baik, baik di dalam kelas maupun di luar kelas. Terlihat dari kegiatan dan keakraban sehari-hari diantara siswa dengan guru, kepala sekolah dan staf TU di sekolah. Sekolah SMA PIRI 1 Yogyakarta merupakan sekolah yang membebaskan siswanya untuk menyampaikan sesuatu, seperti keluhan ten- 
tang sekolah. Keluhan tersebut akan menjadi koreksi sekolah untuk menindak lanjutinya.

Organisasi Siswa Intra Sekolah (OSIS) mengajarkan bagaimana melaksanakan tugas atau kewajiban sebagai anggota, memecahkan masalah, mengevaluasi program sekolah dan dengan komunikasi yang terjalin akan mendapatkan kemudahan untuk melaksanakan proses organisasi sekolah. Adanya organisasi sekolah akan melatih hubungan atau interaksi siswa yang baik.

Selain organisasi di sekolah untuk melatih kerjasama siswa di SMA PIRI 1 Yogyakarta, sekolah juga memberikan tugas kepada siswanya untuk melakukan kegitan studi lingkungan. Studi lingkungan ini melatih siswa untuk saling peduli dan kerjasama terhadap teman-teman sekelompoknya untuk saling memudahkan menyelasikan tugas secara bersama dan mendapatkan hasil yang lebih baik.

Kemampuan Personal.Keterampilan personal yang dimanfaatkan untuk kepentingan diri sendiri. Misalnya dapat mengendalikan emosi dalam diri, dapat menerima nasehat dari orang lain, dan selalu berpikir positif. Pada pembelajaran di kelas XII SMA PIRI 1 Yogyakarta diberikan suatu masalah untuk memecahkan suatu masalah secara kelompok. Hal ini akan melatih keterampilan berpikir siswa untuk memecahkan masalah secara bersama-sama dan mendapatkan pelajaran tentang saling menghargai pendapat orang lain, dan akan mendapatkan solusi dari permasalah.

\section{Pendukung Soft Skill Siswa di SMA PIRI 1 Yogyakarta}

Kemampuan soft skill yang diperoleh siswa SMA PIRI 1 Yogyakarta yaitu kerjasama, kesadaran diri, berfikir rasional, percaya diri, dan komunikasi. Siswa diberi dukungan atau motivasi yang kuat akan selalu melatih kemampuan soft skill. Karena yang mendasari pembelajaran kooperatif, diantaranya adalah teori motivasi dan teori kognitif. Menurut teori motivasi, memberikan penghargaan kepada kelompok sesuai dengan penampilannya akan menciptakan struktur penghargaan antar perorangan sehingga anggota-anggota tersebut akan saling memberi penguatan sosial.

Dukungan yang diberikan kepada siswa di SMA PIRI 1 Yogyakarta tidak hanya dari guru saja namun dukungan seluruh warga sekolah. Dukungan yang diberikan sekolah berkaitan dengan kultur sekolah yang sudah tercipta baik itu di dalam kelas pada pembelajaran yang diberikan guru. Selain motivasi yang diberikan, fasilitas-fasilitas sekolah untuk seluruh warga sekolah merupakan bentuk dukungan. Fasilitas-fasilitas sekolah akan memberi kemudahan didalam pengembangan soft skill siswa. Fasilitas sekolah yang mendukung yaitu studio band yang diberikan kepada siswa yang ingin menyalurkan bakatnya, alat-alat praktikum di laboratorium dan buku-buku ilmu pengetahuan yang ada di perpustakaan serta kultur sekolah yang sudah tercipta di SMA PIRI 1 Yogyakarta

\section{Pembahasan}

Realita kultur sekolah di SMA PIRI 1 Yogyakarta dapat dilihat dari artifak yang mencakup lingkungan fisik dan lingkungan belajar. Lingkungan fisik yang dimaksud dapat dilihat dari taman dan halaman yang rapi, gedung yang rapi dan bagus, interior ruang yang selaras dan sarana ruang yang bersih dan tertata. Tata gedung sekolah, ruang kepala sekolah, ruang guru dan masjid. Kondisi gedung sekolah di SMA PIRI 1 Yogyakarta dengan kondisi baik yang memiliki banyak ruangan untuk fasilitas pembelajaran siswa. Tata ruang kepala sekolah dan ruang guru di SMA PIRI 1 Yogyakarta dengan kondisi rapi, bersih dan baik. Fasilitas gedung sekolah yaitu masjid yang digunakan untuk bersama yang mempertemukan seluruh warga dari komplek sekolah Yayasan PIRI Yogyakarta.

Lingkungan belajar juga terlihat cukup baik dan fasilitas sekolah yang cukup memadai membantu atau memberi kemudahan siswa di SMA PIRI 1 Yogyakarta di dalam pelaksanaan pembelajarannya. Fasilitas perpustakan yang dilengkapi buku-buku pelajaran yang cukup lengkap dan susunan buku rapi membuat siswa menjadi mudah untuk mendapatkan buku. Laboratorium yang ada di SMA PIRI 1 Yogyakarta sangat lengkap dari 
laboratorium biologi, laboratorium fisika, laboratorium kimia, laboratotium komputer, laboratorium bahasa, laboratorium agama, dan fasilitas peralatan praktikum cukup lengkap. Ruang kelas siswa yang nyaman dan fasilitas-fasilitas di dalam ruang kelas juga cukup memadai. Hal ini sangat membantu di dalam pembelajaran siswa di SMA PIRI 1 Yogyakarta.

Bentuk kultur yang dimiliki SMA PIRI 1 Yogyakarta yaitu nilai Islami, nilai kerjasama, nilai disiplin dan apresiasi terhadap prestasi. Nilai Islami yang membiasakan seluruh siswa sebelum pembelajaran dimulai melakukan membaca Al-Qur'an dan berdoa bersama dengan tujuan memberi kemudahan dalam menerimapembelajaran. Melaksanakan shalat dzuhur dan shalat jum'at berjamaah dan kajian islam bagi siswa putri selama waktu shalat jum'at dimulai. Kegiatan pengajian yang diadakan oleh kepala sekolah, guru-guru dan staf tata usaha di setiap satu bulan sekali di sekolah atau di rumah guru-guru secara bergiliran. Budaya $5 \mathrm{~S}$ yaitu senyum, sapa, salam, sopan dan santun yang dilakukan oleh seluruh warga sekolah di SMA PIRI 1 Yogyakarta.

Nilai disiplin juga bukan hanya berlaku untuk siswa namun untuk seluruh warga sekolah di SMA PIRI 1 Yogyakarta. Kedisiplinan yang tercipta berupa tanggungjawab dan kerja sama seluruh civitas sekolah yaitu kepala sekolah, guru-guru dan tata usaha di dalam melaksanakan pekerjaannya.Kerjasama yang terjalin di SMA PIRI 1 Yogyakarta terbilang cukup baik, dengan adanya team work di dalam sekolah menunjukan bahwa seluruh elemen yang ada di dalam sekolah akan terciptanya sikap saling menghargai, saling pengertian dan saling mendukung antar sesama warga sekolah (Hasil wawancara, 2015).Adanya dukungan serta kerjasama antar warga sekolah di dalam lingkungan SMA PIRI 1 Yogyakarta tentunya dapat menghasilkan prestasi bagi sekolah. Bukti dari prestasi tersebut terlihat dari banyaknya piala yang di pajang di atas lemari raung TU. Pihak sekolah SMA PIRI 1 Yogyakarta memang memberikan kebebasan bagi warganya untuk mengikuti segala kegiatan yang bersifat positif dan dapat mengharumkan nama sekolah.

Kepala sekolah sebagai pemimpin sangat mempengaruhi maju dan mundurnya kultur sekolah yang akan mengembangkan kualitas soft skill siswa di SMA PIRI 1 Yogyakarta. Kepala sekolah di SMA PIRI 1 Yogyakarta menerapkan demokratisasi dan eksistensi pembagian tugas serta tanggungjawab terhadap warga sekolah. Kepala sekolah berupaya menerapkan konsep pendidikan dan peningkatan kualitas pendidikan (guru, siswa, kurikulum, bahan ajar dan proses pembelajaran).

Kepala sekolah SMA PIRI 1 Yogyakarta di dalam pengembangkan soft skill siswa membagi tugas kepada wakil-wakil kepala sekolah dan semua guru yang ada di sekolah. Kegiatan pengembangan dan aplikasi terhadap hal-hal yang mendorong soft skill siswa di SMA PIRI 1 Yogyakarta tersebut tampak sekali di dalam kegiatan-kegiatan setiap hari. Setiap pagi tepat pukul 07.00 WIB siswa masuk kelas masing-masing, sebelum memulai pembelajaran semua siswa berdoa bersama, setelah membaca do'a bersama siswa melakukan tadarus Al-qur'an bersama selama 10 menit dan selesai tadarus Al-qur'an bersama siswa menyayikan lagu kebangsaan Indonesia yaitu Indonesia Raya, yang di koordinator oleh staf tata usaha sekolah SMA PIRI 1 Yogyakarta. Kebiasaan ini diharapkan akan meningkatkan soft skill siswa yang berkaitan dengan nilai keagamaannya dan rasa cinta tanah air di SMA PIRI 1 Yogyakarta. Kebiasaan tersebut agar siswa dapat menyerap pembelajaran dengan baik dengan memohon kepada Allah SWA. Kebiasaan ini dapat menigkatkan aqidah akhlak pada siswa dan siswa mempunyai budi pekerti yang baik.

Kultur sekolah di SMA PIRI 1 Yogyakarta dapat mendorong perkembangnya soft skill siswa. Guru mengajarkan cara berdiskusi dan memecahkan suatu masalah. Siswa dilibatkan secara langsung pada pembelajaran studi lingkungan. Siswa mendapatkan pembelajaran dengan melihat dan terlibat langsung pada studi lingkungan. Guru hanya sebagai pembimbing siswa untuk membantu siswa apabila mengalami kesulitan. Pengembangan soft skill dengan studi lingkungan dapat melatih siswa di dalam berkomunikasi den- 
gan orang lain, berkerjasama dengan temanteman sekelas, memberikan kesadaran diri bagi siswa serta mengembangkan kecakapan berpikir rasional kepada orang lain.

Kemampuan soft skill yang diperoleh siswa SMA PIRI 1 Yogyakarta yaitu kerjasama, kesadaran diri, berfikir rasional, percaya diri, dan komunikasi. Siswa diberi dukungan atau motivasi yang kuat akan selalu melatih kemampuan soft skill. Karena yang mendasari pembelajaran kooperatif, diantaranya adalah teori motivasi dan teori kognitif. Dukungan-dukungan yang diberikan kepada siswa di SMA PIRI 1 Yogyakarta tidak hanya dari guru saja namun dukungan seluruh warga sekolah. Dukungan yang diberikan sekolah berkaitan dengan kultur sekolah yang sudah tercipta baik itu di dalam kelas pada pembelajaran yang diberikan guru.Fasilitas-fasilitas sekolah akan memberi kemudahan didalam pengembangan soft skill siswa. Fasilitas sekolah yang mendukung yaitu studio band yang diberikan kepada siswa yang ingin menyalurkan bakatnya, alat-alat praktikum di laboratorium dan buku-buku ilmu pengetahuan yang ada di perpustakaan serta kultur sekolah yang sudah tercipta di SMA PIRI 1 Yogyakarta.

\section{SIMPULAN}

SMA PIRI 1 Yogyakarta merupakan salah satu sekolah swasta yang berada dinaungan Yayasan PIRI (Perguruan Islam Republik Indonesia). Walaupun SMA PIRI 1 Yogyakarta merupakan sekolah swasta Islam, tetapi sekolah ini membuka untuk umum. Kondisi sekolah di SMA PIRI 1 Yogyakarta dapat dilihat dari aspek artifak pada gambaran kondisi sekolah dari lingkungan fisik dan lingkungan belajarnya.

Bentuk kultur sekolah di SMA PIRI 1 Yogyakarta merupakan suatu kebiasaan yang sering dilakukan oleh warga sekolah. Bentuk kultur sekolah yang ada di SMA PIRI 1 Yogyakarta dapat dinilai dari nilai Islami, nilai kerjasama, nilai disiplin, dan apresiasi terhadap prestasi.

Peran utama dalam pengembangan soft skill siswa di SMA PIRI 1 Yogyakarta yaitu pemimpin sekolah atau kepala sekolah.. Kepala sekolah berupaya menerapkan konsep pendidikan dan peningkatan kualitas pendidikan (guru, siswa, kurikulum, bahan ajar dan proses pembelajaran).

Realita soft skill siswa di SMA PIRI 1 Yogyakarta dapat dilihat pada kegiatan-kegiatan yang dilakukan oleh siswa di dalam sekolah dan luar sekolah. Pengembangan soft skill siswa di SMA PIRI 1 Yogyakarta dapat di lihat dari kemampuan interpersonal dan kemampuan personal.

Pendukung soft skill siswa di SMA PIRI 1 Yogyakarta yaitu motivasi dari seluruh warga sekolah dan fasilitas sekolah. Tersediannya fasilitas sekolah yang memadai mulai dari perpustakaan, ruang kelas, laboratorium, studio band, lapangan olahraga.

\section{Saran}

Pengembangan kultur sekolah sangat tergantung pada peran kepala sekolah. Kepala sekolah harus mampu menjadi penggerak perubahan (change-maker) dalam pengembangan kultur akademik, kultur mutu dan kultur sosial dalam lingkungan sekolah. Disarankan agar kepala sekolah lebih ditingkatkan lagi kultur positif yaitu: nilai jujur, saling percaya/social trust, kerjasama/kemitraan, gemar membaca, disiplin, berprestasi, budaya suka memberi penghargaan, dan budaya efisien.

\section{UCAPAN TERIMA KASIH}

Dalam kesempatan ini penulis mengucapkan terima kasih kepada berbagai pihak yang telah membantu pelaksanaan penelitian ini, khususnya pihak SMA PIRI 1 Yogyakarta. Penulis juga mengucapkan terima kasih kepada pembimbing serta dewan redaksi Jurnal Socia atas kesempatan yang diberikan sehingga paper ini dapat diterbitkan pada Jurnal Socia edisi September 2015.

\section{DAFTAR PUSTAKA}

Asmani, J.M. 2009. "Sekolah life skills" lulus siap kerja. Yogyakarta: Diva Press.

Hanum, F. 2011. Sosiologi Pendidikan. Yogyakrta: Kanwa Publiser.

Neff, T.J., \& Citrin, J.M. 2001. Lesson From The Top. New York: Doubleday Business.

Nurkolis. 2006. Manajemen Berbasis Sekolah. 
Jakarta: Grasindo.

Yamin, H.M. 2008. Paradigma Pendidikan Konstruktivistik. Jakarta: GP Press.

Zamroni. 2002. Pedoman Pengembangan Kultur Sekolah. Jakarta: Direktorat pendidikan umum.
Zamroni. 2007. Meningkatkan Mutu Sekolah, Teori, Strategi, dan Prosedur. Jakarta: PSAP Muhammadiyah.

Zamroni. 2013. Manajemen Pendidikan Suatu Usaha Meningkatkan Mutu Sekolah. Yogyakarta: Ombak 